\title{
Occurrence of TEM and SHV among extended-spectrum-beta lactamase producers of some Enterobacteriaceae members
}

\author{
Ashraf A. Kadry, Eman M. EI Masry, Dalia M. Serry \\ Microbiology and Immunology Department, Faculty of Pharmacy, Zagazig University
}

\begin{abstract}
This study aimed for the molecular detection of TEM and SHV genes in Extended-Spectrum beta-lactamases (ESBLs) clinical isolates of Enterobacteriace (Eshericichia coli, Klebsiella pneumoniae and Proteus spp.). ESBLs are one of the main cause of resistance of Enterobacteriace family to beta-lactam antibiotics. The susceptibility of isolates to different beta-lactam and nonbeta lactam antimicrobial agents was performed to identify the proper antimicrobial chemotherapeutics for treatment of infections in case of development of resistance to Extended spectrum beta-lactams. Ninety clinical isolates belong to Enterobacteriacae family ( 54 E. coli, 28 Kl. Pneumonia and 8 Proteus spp) recovered from 220 different clinical specimens (urine, blood, pus and sputum). Thirty (33.3\%) out of 90 isolates were ESBLs producers. The ESBLs producers were more frequent among E. coli isolates (40.7\%), followed by Proteus (25\%) and klebsiella pneumoniae $(21.4 \%)$. Susceptibility testing to Beta-lactams and non beta-lactams was performed by disk diffusion method to all isolates. The bla TEM gene was identified in 14 of E. coli isolates at $504 \mathrm{bp}$. The blaSHV-625 gene was identified in two isolates of Klebsiella pneumoniae at 625bp. Meanwhile blaSHV-1,107 was not detected in any clinical isolates.
\end{abstract}

\section{INTRODUCTION}

Resistance to the extended-spectrum cephalosporins among members of the family Enterobacteriaceae has become a growing worldwide problem (Nordman 1998). Extended -spectrum $\beta$-lactamase-(ESBL) producing bacteria are emerging pathogens in the community, and that clinical laboratories play a critical role for their detection and control.

Although ESBLs have been described in a range of Enterobacteriaceae family from different parts of the world, they are most often identified in Klebsiella pneumoniae, Escherichia coli and Proteus spp. (Bush et al. 1995). The first plasmid-mediated Blactamase was detected in Gram-negative bacteria in Greece in the 1960s and was designated TEM after the name of the patient (Temoneira) who carried the pathogen (Datta and Kontomichalou 1965). TEM-1 is the most common $\beta$-lactamase in Gram-negative bacteria, it can hydrolyze penicillins (ampicillin).The ß-lactamases are quickly spread to other bacteria, after changes in one or few amino acids (Brunton et al. 1986) Compared to the TEMs, the sulphydryl variable (SHV) B-lactamases are similar in biochemical structure but are more common in Klebsiella spp. (Bush et al. 1995).

\section{MATERIALS and METHODS:}

\section{Bacterial isolates}

A total of 220 different clinical specimens (urine, blood, pus and sputum) were obtained from Zgazig-University Hospitals and Al-Ahrar Educational Hospital during the period from October 2010 to April 2012.

These isolates were identified and verified by using standard biochemical reactions according to Collee et al. (1996). All isolates were collected under approved ethical procedures. For long term maintenance of isolates, $900 \mu \mathrm{l}$ of overnight culture in Mueller-Hinton broth of each strain were mixed with $100 \mu \mathrm{l}$ of glycrol and stored at $-80^{\circ} \mathrm{C}$. 


\section{Susceptibility testing}

The antibiotic sensitivity of the isolates to the antimicrobial agents was carried out by the disk diffusion method according to CLSI (2013) on Muller-Hinton agar (Oxoid UK). The following disks (Oxoid UK) were used Cefotaxim (CTX, 30 $\mu$ g), Cefoperazone (CEP, $30 \mu \mathrm{g}$ ), Tetracyclin (TE, $30 \mu \mathrm{g}$ ), Ceftriaxone (CRO, $30 \mu \mathrm{g}$ ), Ceftazidime (CAZ, $30 \mu \mathrm{g}$ ), Cefuroxime (CXm, $30 \mu \mathrm{g}$ ), Aztreonam (ATM, $30 \mu \mathrm{g}$ ), Ciprofloxacin (Cip, $30 \mu \mathrm{g}$ ), Nitrofurantoin (F, $300 \mu \mathrm{g})$, Sulphamethoxazole / trimethoprim (SXT, 25 $\mu \mathrm{g}$ ) and Gentamicin (CN, $10 \mu \mathrm{g})$.

\section{Phenotypic detection of Extended- spectrum beta-lactamases (ESBLs)}

Isolates resistant to ceftazidime antibiotic were tested for ESBLs production by disk diffusion method by using ceftazidim/clavulinic acid (CAZ-CAZ/CAV30/10 $\mu \mathrm{g}$ ). The disk of ceftazidime (CAZ, 30 $\mu \mathrm{g})$ and the disk of (CAZ/CAV, 30/10 $\mu \mathrm{g})$, were placed on the inoculated Mueller-Hinton agar plates. The plates were incubated at $37^{\circ} \mathrm{C}$ for $18 \mathrm{~h}$. Plates were examined and diameters of the inhibition zones were measured in $\mathrm{mm}$, and interpreted according to CLSI (2013). The increase in diameter of inhibition zone of ceftazidime/clavulanate by $5 \mathrm{~mm}$ or more over ceftazidime alone indicates ESBLs production.

\section{Extraction of plasmid DNA}

Five pure colonies of each organism were inoculated into $5 \mathrm{ml}$ of Luria-Bertani broth and inoculated for $20 \mathrm{hr}$ at $37^{\circ} \mathrm{C}$. Cells from $1.5 \mathrm{ml}$ of the overnight culture were harvested by centrifugation at 12,000 rpm for 5 minutes. Plasmid DNA was extracted by using plasmid extraction kits obtained from Fermentas, Germany.

Plasmid DNA extracted from ESBLs producers was electrophoresed from agarose gel. The gel was prepared by adding $0.8 \%$ agarose to $100 \mathrm{ml}$ TAE buffer and microwaved for few minutes for complete dissolution then $10 \mu \mathrm{g} / \mathrm{ml}$ Eithidium-Bromide (Et-Br) were added for DNA staining after slightly cooling of agarose (Sambrook and Russell 2001). Extracted plasmid was mixed with $2 \mu \mathrm{l}$ of $10 \mathrm{X}$ loading buffer and DNA marker was loaded at first slot. The gel was visualized on UV transilluminator and photographed.

\section{PCR amplification}

To amplify TEM and SHV related genes from clinical isolates, the following oligonucleotide primers were used for PCR. For blaTEM-504bp gene, the forward primer was (TTGGGTGCACGA GTGGGTTA) and the reverse primer was (TAATTGTTGCCGGGAAGCTA). For blaSHV-626 gene, forward primer was (TCG GGCCGCGTAGGCATGAT) and reverse primer was (AGCAGGGCGACAATCCGC G) and for blaSHV -1,017bp gene, forward primer was (CGCCGGGTTATTCTTATTTGTCGC) and reverse primer was (TCTTTCCGATGCCGCCGCCAGTCA). A single reaction mixture $(50 \mu \mathrm{l})$ contained $3 \mu \mathrm{l}$ of both forward and reverse primers, $25 \mu 1$ master mix, $1.5 \mu \mathrm{l}$ of template and completed to $50 \mu \mathrm{l}$ by nuclease free water was prepared. In thermal cycler, the following reaction parameters were followed: initial denaturation at $94^{\circ} \mathrm{C}$ for five minutes, Then denaturation at $95^{\circ} \mathrm{C}$ for 30 seconds, annealing at $52^{\circ} \mathrm{C}$ for 30 second for TEM and $68^{\circ} \mathrm{C}$ for 30 seconds for SHV, Extension at $72^{\circ} \mathrm{C}$ for one minute for 30 cycles, and final extension at $72^{\circ} \mathrm{C}$ for 10 minutes. Then the PCR products were separated by electrophoresis in $1.8 \%$ agarose gel, stained with eithidium Bromide $(10 \mu 1$ for100 $\mathrm{ml}$ ), and visualized by UV transilluminator and photographed. DNA ladder was used for size determination.

\section{RESULTS:}

\section{Identification of isolates}

Ninty (90) bacterial isolates were identified as $54(60 \%)$ E.coli, 28 (31.1\%) klebsiella pneumoniae and 8 (8.9\%) Proteus isolates.

\section{Susceptibility testing}

The results of susceptibility are presented in table (1) and interpreted according to CLSI (2013). The susceptibility of E. coli isolates 
Zagazig J. Pharm. Sci., June, 2016

Vol. 25, Issue 1, pp. 68-77

towards beta-lactam antibiotics showed high resistance toward Cefuroxime (88.9\%) followed by ceftazidime $(57.4 \%)$ and revealed sensitivity $(68.5 \%)$ to both ceftriaxone and aztreonam. The susceptibility of Klebsiella pnumoniae isolates showed
ISSN 1110-5089

ISSN (on-line) 2356_9786

resistance $(64.3 \%)$ to cefuroxime .while the isolates revealed sensitivity $64.3 \%$ and $60.7 \%$ respectively to cefotaxime and azteronam. While Proteus isolates showed resistance to cefuroxime $(62.5 \%)$ and revealed sensitivity $(62.5 \%)$ to ceftazidime.

Table (1): Determination of antimicrobial susceptibility pattern of clinical isolates to beta-lactams and non beta-lactams

\begin{tabular}{|c|c|c|c|c|c|c|c|c|c|}
\hline \multirow{2}{*}{$\begin{array}{l}\text { Antimicrobial } \\
\text { Disk }\end{array}$} & \multicolumn{3}{|c|}{ E. coli } & \multicolumn{3}{|c|}{ Kl.pneumoniae } & \multicolumn{3}{|c|}{ PROTEUS spp. } \\
\hline & $\begin{array}{c}R \\
\text { No(\%) }\end{array}$ & $\begin{array}{c}I \\
\text { No }(\%)\end{array}$ & $\begin{array}{l}\text { S } \\
\text { No }(\%)\end{array}$ & $\begin{array}{l}\mathrm{R} \\
\text { No(\%) }\end{array}$ & $\begin{array}{l}\text { I } \\
\text { No }(\%)\end{array}$ & $\begin{array}{l}\text { S } \\
\text { No }(\%)\end{array}$ & $\begin{array}{c}\mathrm{R} \\
\text { No(\%) }\end{array}$ & $\begin{array}{l}\text { I } \\
\text { No }(\%)\end{array}$ & $\begin{array}{l}\mathbf{S} \\
\text { No }(\%)\end{array}$ \\
\hline CAZ & $\begin{array}{l}17 \\
(31.4 \%)\end{array}$ & $\begin{array}{l}9 \\
(16.7) \%\end{array}$ & $\begin{array}{l}28 \\
(51.9 \%)\end{array}$ & $\begin{array}{l}16 \\
(57.1 \%)\end{array}$ & $\begin{array}{l}1 \\
(3.6 \%)\end{array}$ & $\begin{array}{l}11 \\
(39.3 \%)\end{array}$ & $\begin{array}{l}4 \\
(50 \%)\end{array}$ & $\begin{array}{l}2 \\
(25 \%)\end{array}$ & $\begin{array}{l}2 \\
(25 \%)\end{array}$ \\
\hline CEP & $\begin{array}{l}33 \\
(61.1 \%)\end{array}$ & $\begin{array}{l}8 \\
(14.8 \%)\end{array}$ & $\begin{array}{l}13 \\
(24.1 \%)\end{array}$ & $\begin{array}{l}14 \\
(50 \%)\end{array}$ & $\begin{array}{l}5 \\
(17.9 \%)\end{array}$ & $\begin{array}{l}9 \\
(32.1 \%)\end{array}$ & $\begin{array}{l}1 \\
(12.5 \%)\end{array}$ & $\begin{array}{l}3 \\
(37.5 \%)\end{array}$ & $4(50 \%)$ \\
\hline CXM & $\begin{array}{l}1 \\
(1.8 \%)\end{array}$ & $\begin{array}{l}5 \\
(9.3 \%)\end{array}$ & $\begin{array}{l}48 \\
(89 \%)\end{array}$ & $\begin{array}{l}6 \\
(21.4 \%)\end{array}$ & $\begin{array}{l}4 \\
(14.3 \%)\end{array}$ & $\begin{array}{l}18 \\
(64.3 \%)\end{array}$ & $\begin{array}{l}1 \\
(12.5 \%)\end{array}$ & $\begin{array}{l}2 \\
(25 \%)\end{array}$ & $\begin{array}{l}5 \\
(62.5 \%)\end{array}$ \\
\hline CRO & $\begin{array}{l}37 \\
(68.5 \%)\end{array}$ & $\begin{array}{l}4 \\
(7.4 \%)\end{array}$ & $\begin{array}{l}13 \\
(24 \%)\end{array}$ & $\begin{array}{l}14 \\
(50 \%)\end{array}$ & $\begin{array}{l}4 \\
(14.3 \%)\end{array}$ & $\begin{array}{l}10 \\
(35.7 \%)\end{array}$ & $\begin{array}{l}2 \\
(25 \%)\end{array}$ & $\begin{array}{l}3 \\
(37.5 \%)\end{array}$ & $\begin{array}{l}3 \\
(37.5 \%)\end{array}$ \\
\hline CTX & $\begin{array}{l}36 \\
(66.7 \%)\end{array}$ & $\begin{array}{l}6 \\
(11.1 \%)\end{array}$ & $\begin{array}{l}12 \\
(22 \%)\end{array}$ & $\begin{array}{l}18 \\
(64.3 \%)\end{array}$ & $\begin{array}{l}2 \\
(7.1 \%)\end{array}$ & $\begin{array}{l}8 \\
(28.6 \%)\end{array}$ & $\begin{array}{l}3 \\
(37.5 \%)\end{array}$ & $\begin{array}{l}2 \\
(25 \%)\end{array}$ & $\begin{array}{l}3 \\
(37.5 \%)\end{array}$ \\
\hline ATM & $\begin{array}{l}37 \\
(68.5 \%)\end{array}$ & $\begin{array}{l}5 \\
(9.3 \%)\end{array}$ & $\begin{array}{l}12 \\
(22 \%)\end{array}$ & $\begin{array}{l}17 \\
(60.7 \%)\end{array}$ & $\begin{array}{l}1 \\
(3.6 \%)\end{array}$ & $\begin{array}{l}10 \\
(35.7 \%)\end{array}$ & $\begin{array}{l}3 \\
(37.5 \%)\end{array}$ & $\begin{array}{l}1 \\
(12.5 \%)\end{array}$ & $\begin{array}{l}4 \\
(50 \%)\end{array}$ \\
\hline TE & $\begin{array}{l}7 \\
(13 \%)\end{array}$ & $\begin{array}{l}10 \\
(18.5 \%)\end{array}$ & $\begin{array}{l}37 \\
(68 \%)\end{array}$ & $\begin{array}{l}0 \\
(0 \%)\end{array}$ & $\begin{array}{l}4 \\
(14.3 \%)\end{array}$ & $\begin{array}{l}24 \\
(85.7 \%)\end{array}$ & $\begin{array}{l}3 \\
(37.5 \%)\end{array}$ & $\begin{array}{l}3 \\
(37.5 \%)\end{array}$ & $\begin{array}{l}2 \\
(25 \%)\end{array}$ \\
\hline $\mathbf{C N}$ & $\begin{array}{l}47 \\
(87 \%)\end{array}$ & $\begin{array}{l}3 \\
(5.6 \%)\end{array}$ & $\begin{array}{l}4 \\
(7.4 \%)\end{array}$ & $\begin{array}{l}18 \\
(64.3 \%)\end{array}$ & $\begin{array}{l}1 \\
(3.6 \%)\end{array}$ & $\begin{array}{l}9 \\
(32.1 \%)\end{array}$ & $\begin{array}{l}3 \\
(37.5 \%)\end{array}$ & $\begin{array}{l}2 \\
(25 \%)\end{array}$ & $\begin{array}{l}3 \\
(37.5 \%)\end{array}$ \\
\hline CIP & $\begin{array}{l}38 \\
(70.4 \%)\end{array}$ & $\begin{array}{l}2 \\
(3.7 \%)\end{array}$ & $\begin{array}{l}14 \\
(26 \%)\end{array}$ & $\begin{array}{l}11 \\
(39.3 \%)\end{array}$ & $\begin{array}{l}3 \\
(10.7 \%)\end{array}$ & $\begin{array}{l}14 \\
(50 \%)\end{array}$ & $\begin{array}{l}3 \\
(37.5 \%)\end{array}$ & $\begin{array}{l}3 \\
(37.5 \%)\end{array}$ & $\begin{array}{l}2 \\
(25 \%)\end{array}$ \\
\hline SXT & $\begin{array}{l}27 \\
(27 \%)\end{array}$ & $\begin{array}{l}1 \\
(1.9 \%)\end{array}$ & $\begin{array}{l}26 \\
(48 \%)\end{array}$ & $\begin{array}{l}21 \\
(75 \%)\end{array}$ & $\begin{array}{l}1 \\
(3.6 \%)\end{array}$ & $\begin{array}{l}6 \\
(21.4 \%)\end{array}$ & $\begin{array}{l}1 \\
(12.5 \%)\end{array}$ & $\begin{array}{l}0 \\
(0 \%)\end{array}$ & $\begin{array}{l}7 \\
(87.5 \%)\end{array}$ \\
\hline $\mathbf{F}$ & $\begin{array}{l}53 \\
(98 \%)\end{array}$ & $\begin{array}{l}0 \\
(0 \%)\end{array}$ & $\begin{array}{l}1 \\
(1.9 \%)\end{array}$ & $\begin{array}{l}10 \\
(35.7 \%)\end{array}$ & $\begin{array}{l}7 \\
(25 \%)\end{array}$ & $\begin{array}{l}11 \\
(39.3 \%)\end{array}$ & $\begin{array}{l}4 \\
(50 \%)\end{array}$ & $\begin{array}{l}2 \\
(25 \%)\end{array}$ & $\begin{array}{l}2 \\
(25 \%)\end{array}$ \\
\hline & $\mathrm{CEP}=$ & $\begin{array}{l}\text { foperazon } \\
\text { racycline }\end{array}$ & $\mathrm{CXM}=\mathrm{c}$ & foruxim & $1 \mathrm{~A}=\mathrm{cc}$ & $\begin{array}{l}\mathrm{xim} \text { CRO } \\
\mathrm{xPT}-\mathrm{Sul}\end{array}$ & $\begin{array}{l}\text { ceftriaxo } \\
\text { hamethox }\end{array}$ & $\begin{array}{r}\text { ATM } \\
\text { ole-Trim }\end{array}$ & $\begin{array}{l}\text { treonam } \\
\text { porime }\end{array}$ \\
\hline
\end{tabular}

On the other hand the susceptibility of clinical isolates to non beta-lactams showed that E. coli isolates had high sensitivity to nitrofurantoin (98\%) followed by gentamycin 
(87\%) and ciprofloxacin (70.4\%). while the same isolates showed resistance $(68.5 \%)$ to tetracycline. In addition, Klebsiella pnumoniae isolates had high sensitivity reached about (75\%) to sulphamethoxazoletrimethoprim followed by $(64.3 \%)$ to gentamycin and showed high resistance toward tetracycline $(85.7 \%)$ and $(57.1 \%)$ to ciprofloxacin. Proteus isolates revealed sensitivity $(62.5 \%)$ to nitrofurantoin followed by ciprofloxacin $(37.5 \%)$ and high resistance $(87.5 \%)$ to sulphamethoxazole-trimethoprim.
ISSN (on-line) 2356_9786

\section{Phenotypic detection of Extended Spectrum beta- lactamases (ESBLs)}

Detection of ESBLs was done by

Double Disk Diffusion method (figure 1) and interpreted according to CLSI (2013). The enhancement in zone of inhibition by $5 \mathrm{~mm}$ or more of ceftazidim/clavulinic acid over ceftazidime alone is indicative of a positive test. Among the 90 clinical isolates $30(33 \%)$ were ESBLs producers. Whereas $(40.7 \%)$

E.coli isolates were ESBLs producers, $(21.4 \%)$ of $K$. pneumoniae and $25 \%$ of Proteus isolates were ESBLs producer

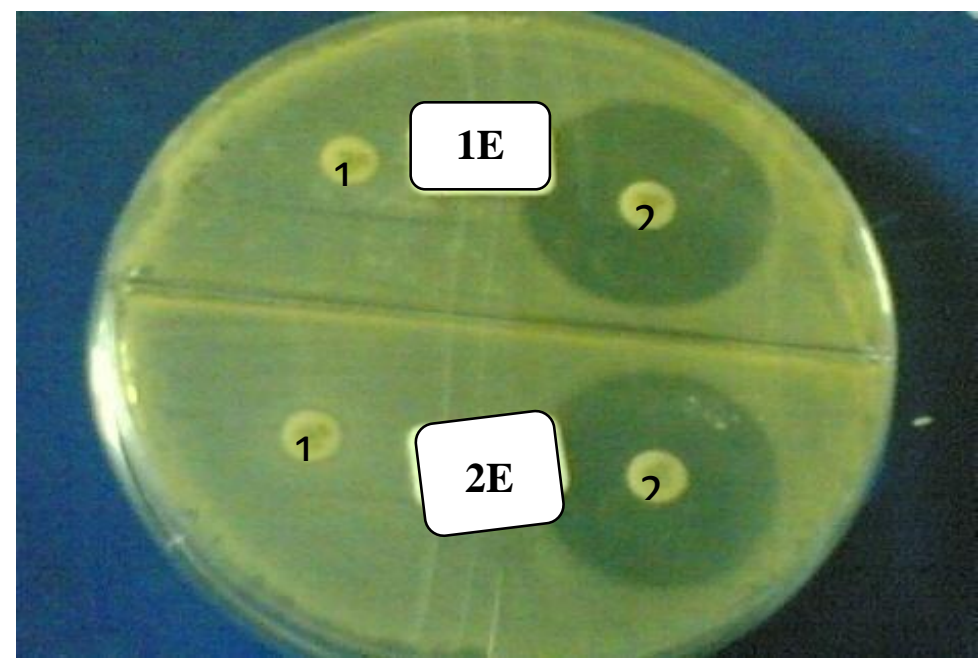

1=ceftazidime $2=$ ceftazidime/clavulinic $\mathrm{E}=$ E.coli

Figure 1: presentive of Extended-spectrum B-lactamase screening in E.coli isolates 1 and 2.

\section{The susceptibility of ESBLs to non beta- lactams}

The ESBLs producers showed high susceptibility to nitrofurantoin $(83.3 \%)$ and gentamicin $(70 \%)$ and ciprofloxacin $(63.3 \%)$. On other hand, isolates revealed high resistant to tetracycline $(84.6 \%)$ followed by sulphamethoxazole-trimethoprim $\quad(56.7 \%)$ (Table 2)

\section{PCR amplification}

The thirty ESBL producers identified as 22 E. coli, 6 K. pneumoniae and two Proteus isolates were subjected to plasmid screening as shown in figure (2).

The ESBLs producers were subjected to plasmid extraction and screened by gel electrophoresis. The results revealed (15/30) $50 \%$ of ESBLs producers have only one plasmid and (9/30) 30\% have two plasmids, (4/30) $13.3 \%$ have 3 plasmids and finally only two isolates $(6.7 \%)$ have four plasmids

The ESBLs isolates were subjected to amplification of bla TEM and bla SHV genes. The blaTEM -504bp was amplified in 14 out of $22(63.6 \%) E$. coli ESBL producers and in 2 out of $6(33.3 \%) \mathrm{K}$. pnumoniae isolates (Figure 3). Meanwhile; TEM was not detected in any Proteus isolates. The bla SHV-626 $b p$ was amplified in $2 K$. pneumoniae isolates as shown in figure (4). While blaSHV-1,107 bp was not detected in any isolate in this investigation 
Table (2): Susceptibility of ESBLs isolates to non beta-lactams

\begin{tabular}{ccc}
\hline & \multicolumn{2}{c}{ Susceptibility of ESBLs isolates } \\
\cline { 2 - 3 } Non beta-lactams & Resistant \% & Sensitive \% \\
Ciprofloxacine & 36.7 & 63.3 \\
Tetracycline & 84.6 & 14.9 \\
GentamIcine & 30 & 70 \\
Nulphamethoxazoletrimethoprime & 56.7 & 43.3 \\
Nitrofurantoin & 13.7 & 83.3 \\
\hline
\end{tabular}

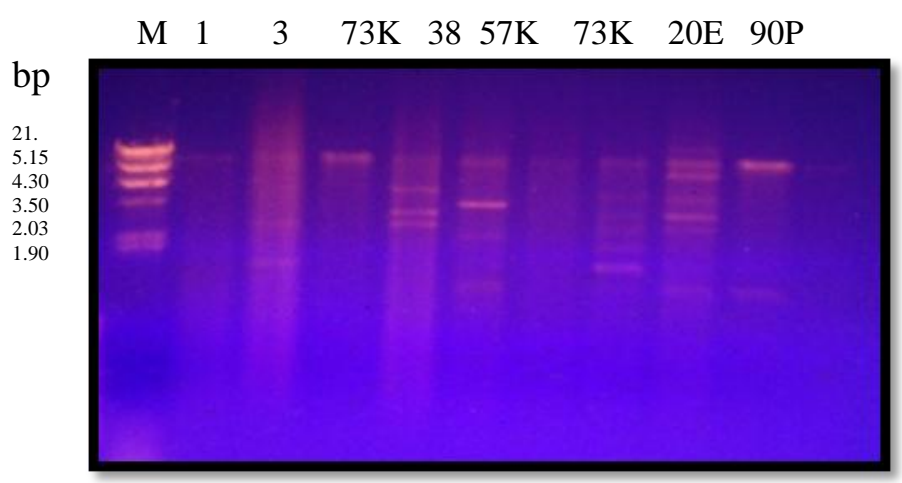

Figure 2: plasmid profiles of representive isolates on agarose gel electrophoresis $\mathrm{M}=$ molecular weight marker $E=E$.coli $K=K$. pneumoniae $P=$ Proteus isolates

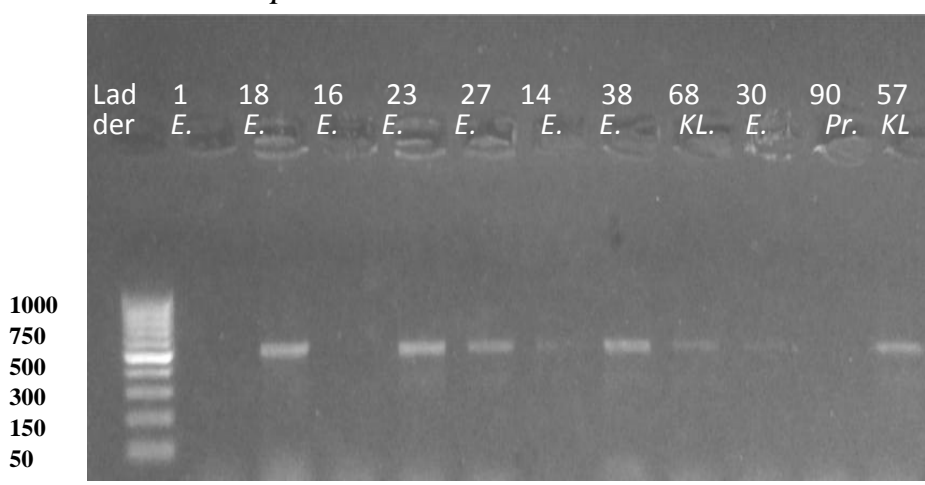

Figure 3: PCR amplification of TEM (504 -bp) genes from of representive clinical isolates on agarose gel electrophoresis. $\mathrm{M}=$ molecular weight marker $E=$ E.coli $K=K$. pneumoniae $P=$ Proteus

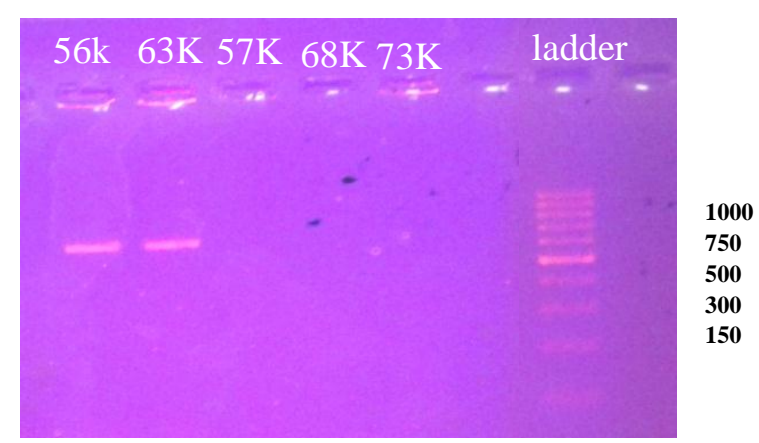

Figure 5: PCR amplification of SHV (626-bp) from plasmid extracts of representive clinical isolates on agarose gel electrophoresis. $\mathrm{M}=$ molecular weight marker $\mathrm{E}=\mathrm{E}$.coli $K=K$. pnumoniae 


\section{DISCUSSION:}

Ninety clinical isolates were obtained from different clinical specimens of urine, blood, sputum and pus. The frequency of isolates was as follows: $(60 \%$ E.coli, $31.1 \%$ Klebsiella pneumoniae and $8.9 \%$ Proteus spp.). These isolation rates were in agreement with that reported by Fam et al. (2014) and Alipourfar and Nili. (2010).

The isolates were tested for their antimicrobial susceptibilities by the Disk Diffusion technique and interpreted according to the CLSI (2013). Susceptibility of E. coli clinical isolates towards beta-lactam antibiotics (table 1) revealed high sensitivity of isolates to ceftriaxone which was lower than that obtained by Hryniewicza et al. (2010). In this study high resistance of $E$. coli isolates to ceforuxime was similar to that reported by Leveristin et al. (2003). Moreover, the resistance to ceftazidim was lower than that reported by Hryniewicza et al. (2010).

The susceptibility of $K$. pneumoniae isolates toward beta-lactam antibiotics (table1) showed high susceptibility of $K$. Pnumoniae to cefotaxim and azteronam which was lower than that reported by Romanus et al (2013). On the other hand, high resistance of $K$. pneumoniae to ceforuximewas in agreement with that reported by Ullah et al. (2009) and lower than that reported by Romanus et al. (2013). The resistance to ceftazidime in this study was in agreement with that reported by Lee et al. (2006).

High susceptibility of Proteus isolates to both cefotaxim and azteronam but the susceptibility of Proteus was lower than that reported by Wang et al. (2014) and Adamus et al. (2014). On the other hand; resistance of Proteus isolates to ceforuxime, ceftazidim and cefoperazone was lower than that obtained by Wang et al. (2014).

Bacterial resistance to these betalactams has increased dramatically with
ESBLs contributing to this increase (Paterson and Bonomo 2005). All isolates were subjected to susceptibility tests to non beta-lactam antimicrobial agents to be used as another choice in treatment in case of resistance or development of resistance of bacteria towards beta-lactams.

In this study susceptibility of $E$. coli isolates to non beta-lactams as nitrofurantoin, Gentamicin and ciprofloxacin (table 1) was higher than the results obtained by Alipourfard and Nilli (2010). E. coli isolates showed high resistance to tetracycline and that was in agreement with that reported by sabir et al. (2014).

Susceptibility of $K$. pneumoniae isolates to non beta-lactams revealed high susceptibility to sulphamethoxazoletrimethoprime and this sensitivity was higher than that reported by Romanus et al. (2013). Susceptibility to Gentamicin was in agreement with that reported by lee $e t$ al. (2004). Klebsiella pneumoniae isolates in this study revealed high resistance to tetracycline which was higher than that reported by lee et al. (2004).

Sensitivity of Proteus isolates to nitrofurantoin was in agreement with that reported by Romanus et al. (2013) while the sensitivity to ciprofloxacin was higher than that reported by Tijjani et al. (2012). Resistance of Proteus isolates to Gentamicin was in agreement with that reported by Tijjani et al. (2012).

In Gram-negative pathogens, betalactamases remain the most important contributing factor to beta-lactam resistance, and their increasing prevalence (Medeiros, 1997). In this study, $33.3 \%$ of isolates were ESBLs producers which was lower than that reported by Kaur and Aggarwa (2013) and was higher than that reported by Kumar et al. (2014).

The highest percentage of ESBL production was shown among E. coli $(40.7 \%)$ in agreement with that reported by Kumar et al. (2014). On the other hand, 
$25 \%$ of Proteus spp. and $21.4 \%$ of $K$. pneumoniae were ESBL producers. In a study performed by Kumar et al. (2014), ESBLs were predominantly present among Klebsiella spp. (32.8\%), while in Proteus spp. Only $1.6 \%$ of the isolates were ESBLs producers.

The susceptibility of $30 \quad(33.3 \%)$ ESBL isolates showed high resistant to tetracycline and sulphamethoxazoletrimethoprime which is higher than that reported by Morosini et al. (2006) and Hosoglu et al. (2007).

Susceptibility of ESBLs producers to nitrofurantoin $(83.3 \%)$ was in agreement with that reported by Hosoglu et al. (2007). In addition, the high susceptibility of ESBLs producers to gentamicin and ciprofloxacin were in agreement with that reported by Paterson and Bonomo (2005).

ESBLs are often encoded by genes located on plasmids and on chromosome. These plasmids might carry genes of resistance to other antimicrobial agents. Plasmid DNA extracted from ESBLs producers were screened for the presence of TEM, and SHV genes using the PCR amplification technique. Amplifying fragment of approximate 504-bp for blaTEM gene; 626-bp and 1,017-bp for blaSHV genes were performed. The blaTEM gene, which is responsible for resistance to ESBLs-lactams was present in 14 out of $22(63.6 \%)$ of $E$. coli isolates, 2 out of $6(33.3 \%)$ of K. pneumoniae and not detected in any Proteus isolates. The blaSHV gene (626-bp) gene was detected only in two $k$. pneumonia isolates. The

\section{REFERENCES:}

Adamus-Bialek W., Zajac E., Parniewski P., and Kaca W. (2014) Compaeison of antibiotic resistance patterns in collections of Escherichia coli and Proteus mirabilis uropathogenic strains 40(4): 3429-3435

Alipourfard, I., and Nili N. Y. (2010): Antibiogram of Extended Spectrum Beta-
ISSN (on-line) 2356_9786

blaSHV gene $(1,107)$ was not detected in any clinical isolates. The data presented in this study revealed the predominance of blaTEM genes in ESBLs producers in these hospitals.

Cao et al. (2002) reported that blaTEM genes were found in (84.3\%) of $E$. coli isolates and (38.4\%) of K. pneumonia isolates and were detected in all Proteus isolates.

In one study, the bla SHV-like genes were found in $54 \%$ of $K$. pneumoniae isolates and in (44\%) E. coli isolates and not detected in Proteus spp. (Cao et al., 2002).This study indicated that the 20 isolates out of $30(66.6 \%)$ which were ESBLs, 53.3\% were carrying blaTEM gene, $6.6 \%$ were carrying the blaSHV gene. Perilli et al. (2002) reported that $88 \%$ were found to carry either the blaTEM or the blaSHV gene or both genes .Of those $88 \%$ of isolates $32.6 \%$ were carrying blaTEM genes $35 \%$ were carrying the blaSHV genes

\section{CONCLUSION}

This paper aims to illustrate the spreading of extended-spectrum blactamase-(ESBL) producing bacteria among emerging pathogens of Enterobacteriace members in this community. The data revealed the predominance of blaTEM genes in ESBLs isolates in these hospitals. According to this investigation, the drugs recommended to be used in treatment of such infection were nitrofurantoin, gentamicin and ciprofloxacine (quinolone, aminoglycides).

lactamase (ESBL) producing Escherichia coli and Klebsiella pneumoniae isolated from Hospital Samples. Bangladesh. J. Med Microbiol .04 (01): 32-36.

Brunton J., Clare D., and Meier M.A. (1986): Molecular epidemiology of antibiotic resistance plasmids of Haemophilus species and Neisseria gonorrhoeae. Rev Infect Dis. 8(5):713-24 
Bush K., Jacoby G. A. and Medeiros A. A. (1995): A functional classification scheme for beta-lactamases and its correlation with molecular structure. Antimicrob. Agents Chemother. 39:12111233.

Cao V., Lambert T., Nhu D. Q., Loan H. K., Hoang N. K., Arlet G., and Courvalin P. (2002): Distribution of ExtendedSpectrum $\beta$-Lactamases in Clinical Isolates of Enterobacteriaceae in Vietnam. Antimicrob Agents Chemother. 46(12): 3739-3743.

Clinical and laboratory standards institute (CLSI) 2013. Performance standards for antimicrobial disk susceptibility tests approved standards. Clinical and laboratory standards institute, Wayne, PA.

Collee, J. G; Miles, R.S.; Watt, B. (1996): Tests for the identification of bacteria. 14th edition. Churchill Livingstone, New York.

Datta, N., and Kontomichalou P. (1965): Penicillinase synthesis controlled by infectious $\mathrm{R}$ factors in Enterobacteriaceae. Nature 208: 239241.

Fam, N., Gamal D., El Said M., Aboul-Fad L., El Dabei E., El Attar S., Sorur A., Fouad S., and Klena J., (2013): Detection of Plasmid-Mediated AmpC BetaLactamases in Clinically Significant Bacterial Isolates in a Research Institute Hospital in Egypt. Life Science Journal 2013; 10(2): 2294-2304

Hryniewicza, K., Szczypa K., Sulikowska A., Jankowski K., Betlejewska K., and Hryniewicz W. (2001): Antibiotic susceptibility of bacterial strains isolated from urinary tract infections in Poland Journal of Antimicrobial Chemotherapy (2001) 47, 773-780.

Kaur M., and Aggarwal A. (2013): Occurrence of the CTX-M, SHV and the TEM Genes among the Extended Spectrum $\beta$-Lactamase Producing Isolates of Enterobacteriaceae in a
ISSN (on-line) 2356_9786

Tertiary Care Hospital of North India. Journal of clinical and diagnostic research. 7(4):642-645.

Kumar, S., Mehra S. K., and Kanta R.C. (2014): Extended Spectrum BLactamases among Clinical Isolates of Enterobacteriaceae sp.: Prevalence and Susceptibility Pattern at A Tertiary Care Hospital. Sch. J. App. Med. Sci. 2(2D):862-864.

Lee K., Lim C. H., Cho J. H., Lee W. G., Uh Y., Kim H. J., Yong D., and Chong Y. (2006): High prevalence of ceftazidimeresistant Klebsiella pneumoniae and increase of imipenemresistant Pseudomonas aeruginosa and Acinetobacter spp. in Korea: a KONSAR Program in Yonsei Med J. 47(5): 634-645.

Lee, S. O., Lee E. S., Park S. Y., Kim S. Y., Seo Y. H., and Cho Y. K. (2004): Reduced use of third-generation cephalosporins decreases the acquisition of extended-spectrum beta-lactamaseproducing Klebsiella pneumoniae. Infect. Control Hosp. Epidemiol. 25:832-837.

Leverstein-van H. M. A, Blok H.E., Donders A. R., Paauw A., Fluit A. C., Verhoef J. (2003): Multidrug resistance among Enterobacteriacae is strongly associated with the presence of integrons and is independent of species or isolated origin. Journal of infectious diseases 187:251259.

Medeiros, A. A. (1997): Evolution and dissemination of beta-lactamases accelerated by generations of beta-lactam antibiotics. Clin. Infect. Dis. 24 Suppl. 1:S19-45.

Morosini, M. García-Castillo M., Coque T. M., Valverde A., Novais A., Loza E., Baquero F., and Cantón R. (2014): Antibiotic Co-resistance in Extendedspectrum- $\beta$-Lactamase-Producing Enterobacteriaceae and in vitro activity of Tigecycline. Antimicrob Agents Chemother. 50(8): 2695-2699. 
Nordmann, P. (1988): Trends I beta-lactam resistace among Enterobacteriacae. Cli. Infect. Dis. 27(Suppl. 1):S100-S106.

Paterson D.L., and Bonomo R.A. (2005): "Extended-spectrum beta-lactamases: aclinical update". Clin. Microbiol. Rev. 18 (4): 657-86.

Perilli, M. , Dell'Amico E., Segatore B., de Massis M. R., Bianchi C., Rossolini G. M., Toniolo A., Nicoletti G., and Amicosante G. (2002): Molecular characterization of Extended-spectrum $\beta$ lactamases produced by nosocomial isolates of Enterobacteriaceae from an Italian nationwide survey. J. clin. Microbial.40(2):611-614

Romanus I. I., Emmanuel N. A., Ngozi A. F., Onyinyechi U. E., Chidiebube N. A., Egwu O. A., and Nnenna N. T. (2013): Antibiotic susceptibility patterns of bacterial isolates from hospitalized patients in Abakaliki. International Research Journal of Basic and Clinical Studies. 1(4): 46-52.

Sabir S., Anjum A. A., Ijaz T., Ali M. A., Khan M. R., and Nawaz M. (2014): Isolation and antibiotic susceptibility of E. coli from urinary tract infections in a
ISSN (on-line) 2356_9786

tertiary care hospital. Pak J Med Sci .30(2):389-392.

Sambrook, J., and Russell, D. W. (2001): Molecular cloning: A laboratory manual, 3rd edition. Cold spring Harbor laboratory press, New York.

Tijjani, J., Arzai, A. H. and Sadiq, N. M. (2012): pattern of extended spectrum beta-lactamase producers in gram negative urogenital isolates in Kano, Nigeri .Bayero Journal of Pure and Applied Sciences, 5(1): 20 - 25.

Ullah F. T, Malik S.A., and Ahmed J. (2009): Antimicrobial susceptibility pattern and ESBL prevalence in Klebsiella pneumoniae from urinary tract infaections in the North-West Pakistan. African journal of microbiology research Vol. 3(11) pp. 676-680.

Wang J.T., Chen P-C., Chang S-C., Shiau YR., Wang H-Y., Lai J-F., Huang I W., Tan M-C., Lauderdale T. L. Y. (2014): Antimicrobial susceptibilities of Proteus mirabilis: a longitudinal nationwide study from the Taiwan surveillance of antimicrobial resistance (TSAR) program $B M C$ Infectious Diseases 14:486. 


\section{التعرف علي جيني التيم و الشيف بين العزلات الاكلينكية من عائلة الأنتيرويكتريسي والمنتجة}

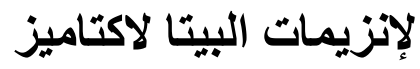

اشرف أحمد قدري، ايمان محمود المصري، الأنيز، داليا سري

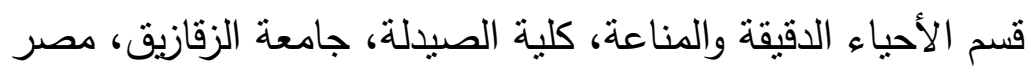

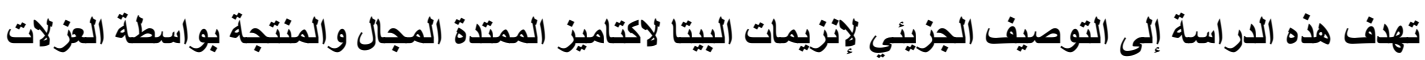

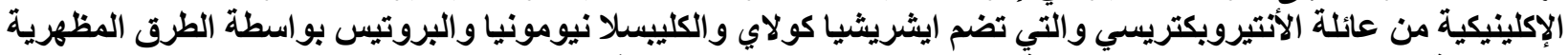

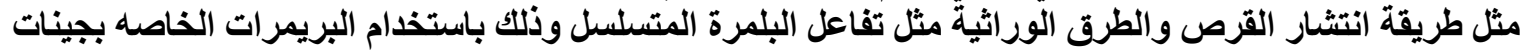
البيتالاكتاميز.

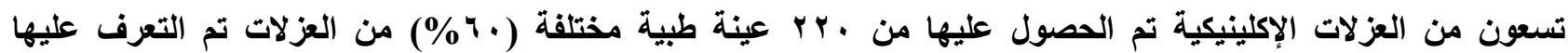

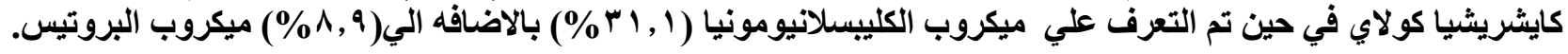

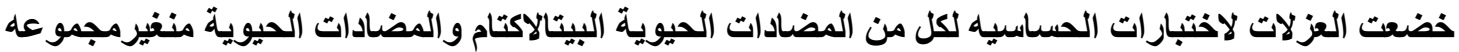

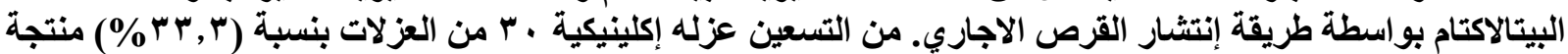

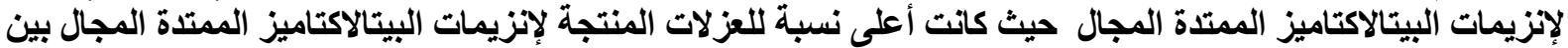

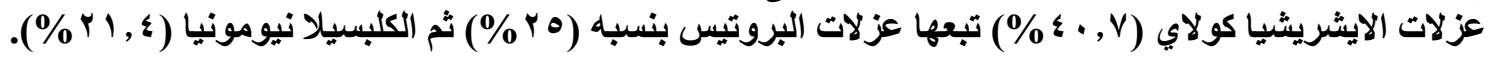

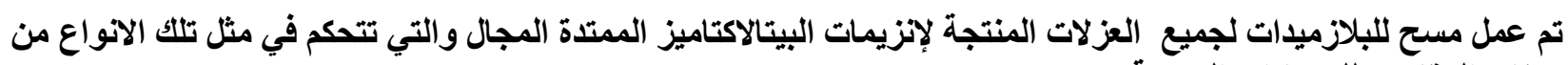

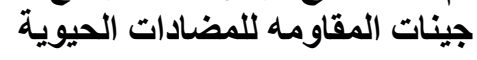

و عليها باستخام جهاز البلمرة SHV و TEM البلازميدات المستخلصة من تلك العزلات تم فحص وجود جينات الـ

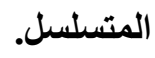

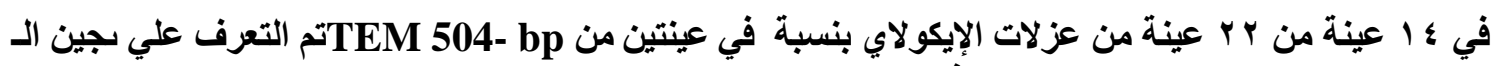
الكلبسيلا نيومونيا، ولم يتم التعرف عليه في عزلات عن الات والبروتيس.

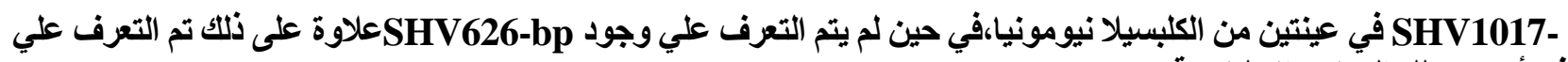
في أي من تلك الغزلات الإكلينيكية 